\title{
Accelerated dissolution of iron oxides in ice
}

\author{
D. Jeong ${ }^{1, *}$, K. Kim ${ }^{1,}$, and W. Choi ${ }^{1}$ \\ ${ }^{1}$ School of Environmental Science and Engineering, Pohang University of Science and Technology (POSTECH), \\ Pohang 790-784, Korea \\ *These authors contributed equally to this work.
}

Correspondence to: W. Choi (wchoi@ postech.edu)

Received: 26 July 2012 - Published in Atmos. Chem. Phys. Discuss.: 13 August 2012

Revised: 31 October 2012 - Accepted: 15 November 2012 - Published: 23 November 2012

\begin{abstract}
Iron dissolution from mineral dusts and soil particles is vital as a source of bioavailable iron in various environmental media. In this work, the dissolution of iron oxide particles trapped in ice was investigated as a new pathway of iron supply. The dissolution experiments were carried out in the absence and presence of various organic complexing ligands under dark condition. In acidic $\mathrm{pH}$ conditions $(\mathrm{pH}$ 2,3 , and 4 ), the dissolution of iron oxides was greatly enhanced in the ice phase compared to that in water. The dissolved iron was mainly in the ferric form, which indicates that the dissolution is not a reductive process. The extent of dissolved iron was greatly affected by the kind of organic complexing ligands and the surface area of iron oxides. The iron dissolution was most pronounced with high surface area iron oxides and in the presence of strong iron binding ligands. The enhanced dissolution of iron oxides in ice is mainly ascribed to the "freeze concentration effect", which concentrates iron oxide particles, organic ligands, and protons in the liquid like ice grain boundary region and accelerates the dissolution of iron oxides. The ice-enhanced dissolution effect gradually decreased when decreasing the freezing temperature from -10 to $-196^{\circ} \mathrm{C}$, which implies that the presence and formation of the liquid-like ice grain boundary region play a critical role. The proposed phenomenon of enhanced dissolution of iron oxides in ice may provide a new pathway of bioavailable iron production. The frozen atmospheric ice with iron-containing dust particles in the upper atmosphere thaws upon descending and may provide bioavailable iron upon deposition onto the ocean surface.
\end{abstract}

\section{Introduction}

Iron is an essential micronutrient controlling the metabolism and growth of organisms, an essential element in metalloenzymes, and an electron transfer mediator in various biological systems (Tortell et al., 1996; Falkowski et al., 1998; Morel and Price, 2003; Alexova et al., 2011). In the open ocean, input of iron dominantly comes from the atmospheric deposition through aeolian dust transport (Jickells et al., 2005; Mahowald et al., 2005). Iron-containing aeolian dust particles may serve as efficient ice nuclei (Pruppacher and Klett, 1997), and thus can be incorporated in atmospheric ice in the upper troposphere. The frozen atmospheric ice particles thaw upon descending and provide bioavailable iron upon deposition onto the ocean surface (Fan et al., 2006). Iron in aerosol particles is mainly present as iron oxides and oxyhydroxides and their dissolution process is an essential mechanism for the production of bioavailable iron. Extensive works have investigated the dissolution of iron oxides under both dark and irradiation conditions with changing various experimental parameters (Rubasinghege et al., 2010; Schwertmann, 1991; Waite and Morel, 1984; Journet et al., 2008; Shi et al., 2011a, b; Faust and Hoffmann, 1986; Bligh and Waite, 2010). However, all previous works on iron oxide dissolution were carried out in aqueous solution except our recent study which found that the photoreductive dissolution of iron oxides is highly accelerated in ice under solar irradiation (Kim et al., 2010).

Chemical reactions taking place in ice can be very different from the aqueous counterparts (Takenaka et al., 1992, 1996; Kuo et al., 2011; Kim and Choi, 2011; McNeill et al., 2012; Guzman et al., 2006, 2007; Boxe and Saiz-Lopez, 2008; Cheng et al., 2010). The differences in reaction are 
Table 1. Summary of the properties of iron oxide samples.

\begin{tabular}{lrrrr}
\hline Iron oxide & $\begin{array}{r}\text { BET specific } \\
\text { surface area }\left(\mathrm{m}^{2} \mathrm{~g}^{-1}\right)\end{array}$ & $\begin{array}{r}\zeta \text {-potential }^{\mathrm{a}} \\
(\mathrm{mV})\end{array}$ & $\begin{array}{r}\text { crystallite size }^{\mathrm{b}} \\
(\mathrm{nm})\end{array}$ & $\begin{array}{r}\text { hydrodynamic }_{\text {diameter }}{ }^{\mathrm{a}}(\mathrm{nm}) \\
\text { diam }^{2}\end{array}$ \\
\hline$\gamma-\mathrm{Fe}_{2} \mathrm{O}_{3}$ (maghemite) & 36 & $32 \pm 1$ & $25 \pm 3$ & $292 \pm 37$ \\
$\alpha-\mathrm{FeOOH}$ (goethite) & 178 & $25 \pm 1$ & $41 \pm 2$ & $480 \pm 57$ \\
$\mathrm{Fe}_{3} \mathrm{O}_{4}$ (magnetite) & 50 & $17 \pm 5$ & $25 \pm 2$ & $294 \pm 7$ \\
$\alpha-\mathrm{Fe}_{2} \mathrm{O}_{3}$ (hematite) & 8 & $12 \pm 6$ & $81 \pm 21$ & $580 \pm 105$ \\
$\gamma-\mathrm{FeOOH}$ (lepidocrocite) & 75 & $21 \pm 5$ & $37 \pm 3$ & $297 \pm 42$ \\
\hline
\end{tabular}

${ }^{a}$ Values were measured at $\mathrm{pH} 3$ at which the majority of the experiments were conducted.

$\mathrm{b}$ Determined by the Scherrer equation from X-ray diffraction analysis.

mainly ascribed to the "freeze concentration effect", which refers to the phenomenon that organic/inorganic solutes, protons, and dissolved gases are excluded from the ice crystals and subsequently concentrated in the liquid-like grain boundary region (Takenaka et al., 1996). This work further advances and generalizes our previous finding of enhanced photoreductive dissolution of iron oxides in ice (Kim et al., 2010). The dissolution of iron oxides in ice was investigated under dark condition to find that the dissolution can be markedly enhanced in ice via a non-reductive process even in the absence of light.

\section{Materials and methods}

\subsection{Chemicals and materials}

Commercial iron oxide particles used in this study include maghemite $\left(\gamma-\mathrm{Fe}_{2} \mathrm{O}_{3}\right.$ : Aldrich), goethite $(\alpha-\mathrm{FeOOH}$ : Aldrich), magnetite $\left(\mathrm{Fe}_{3} \mathrm{O}_{4}\right.$ : Aldrich), hematite $\left(\alpha-\mathrm{Fe}_{2} \mathrm{O}_{3}\right.$ : Aldrich), and lepidocrocite ( $\gamma$-FeOOH: LANXESS Corp). In order to enhance the dispersion of particles, goethite and magnetite were ground into fine particles. Organic complexing ligands such as formic acid, acetic acid, formaldehyde, and Desferrioxamine B (DFOB) were all purchased from Aldrich. Suwannee River fulvic acid (FA) and humic acid (HA) were purchased from the International Humic Substances Society (http://www.humicsubstances.org).

\subsection{Characterization of iron oxides}

Crystallinity and size of five iron oxide samples (i.e. maghemite, goethite, magnetite, hematite, and lepidocrocite) were determined by powder X-ray diffraction on a PANalytical X'Pert diffractometer $\left(\mathrm{Cu} \mathrm{K} \mathrm{K}_{\alpha}\right.$ radiation) with an $X^{\prime}$ Celerator detector. The $\mathrm{N}_{2}$ BET specific surface areas of iron oxides were obtained on a Mirae SI nanoPorosity-XQ analyzer. The $\zeta$-potential and hydrodynamic diameter of the iron oxide samples were measured at $\mathrm{pH} 3$ (main $\mathrm{pH}$ condition of dissolution experiments) using an electrophoretic light scattering spectrophotometer (ELS 8000, Otsuka). The analyzed properties of iron oxide samples were summarized in Table 1 . The iron oxides used in the study may represent the environmental samples well in terms of the particle size $(<100 \mathrm{~nm})$ and surface area. The crystal size of soil iron oxides ranges from a few to several hundred $\mathrm{nm}$ and the surface area can be as small as $<1 \mathrm{~m}^{2} \mathrm{~g}^{-1}$ for massive crystals and as large as $100 \mathrm{~m}^{2} \mathrm{~g}^{-1}$ for fine crystals (Cornell, 1996).

\subsection{Experimental procedure}

Aqueous dispersion of iron oxide in deionized water was prepared at a concentration of $0.2 \mathrm{~g} \mathrm{~L}^{-1}$. Aliquots of HA or FA $(100 \mathrm{ppm})$, DFOB $(500 \mu \mathrm{M})$ or other organic acids $(600 \mathrm{mM})$ were then added to make a desired concentration (1 ppm HA or FA, $50 \mu \mathrm{M}$ DFOB, $6 \mathrm{mM}$ formic/acetic/formaldehyde). The iron oxide suspension was unbuffered and air-equilibrated. The initial $\mathrm{pH}$ of the suspension was adjusted to $2,3,4,5$, and 8 with $\mathrm{HCl}$ and $\mathrm{NaOH}$. The initial solution $\mathrm{pH}$ was adjusted within \pm 0.05 accuracy. Five milliliter of this suspension sample was placed in a conical tube $(15 \mathrm{~mL})$ and then frozen in an ethanol bath cooled at $-20^{\circ} \mathrm{C}$. In the case of temperature-dependent experiments, ethanol bath $\left(-10,-20\right.$, and $\left.-30^{\circ} \mathrm{C}\right)$, deep freezer $\left(-70^{\circ} \mathrm{C}\right)$, and liquid nitrogen $\left(-196^{\circ} \mathrm{C}\right)$ were used to control the temperature. The aqueous samples were kept in ambient temperature $\left(20-25^{\circ} \mathrm{C}\right)$. Both frozen and aqueous samples were kept in the dark. There was a thin layer of iron oxide particles sedimented at the bottom of the tube but most particles were well dispersed throughout the reactor tube both in aqueous and ice samples. Each tube containing $5 \mathrm{~mL}$ of iron oxide suspension was sampled at regular time intervals (i.e. 24, 48, and $72 \mathrm{~h}$ ). The ice samples were then thawed in lukewarm water $\left(30-40^{\circ} \mathrm{C}\right)$ for further analysis. Experiments at a given condition were carried out at least 3 times to confirm reproducibility.

\subsection{Analysis of dissolved iron}

The dissolved iron was colorimetrically measured by 1,10 phenanthroline method (Stucki and Anderson, 1981). After thawing the ice samples in lukewarm water $\left(30-40^{\circ} \mathrm{C}\right.$, within $5 \mathrm{~min}$ ), the aqueous and ice samples were both filtered through a $0.45-\mu \mathrm{m}$ filter to remove iron oxide particles. Ferrous $\left(\mathrm{Fe}^{2+}\right)$ analysis was carried out by adding $2 \mathrm{~mL}$ of 

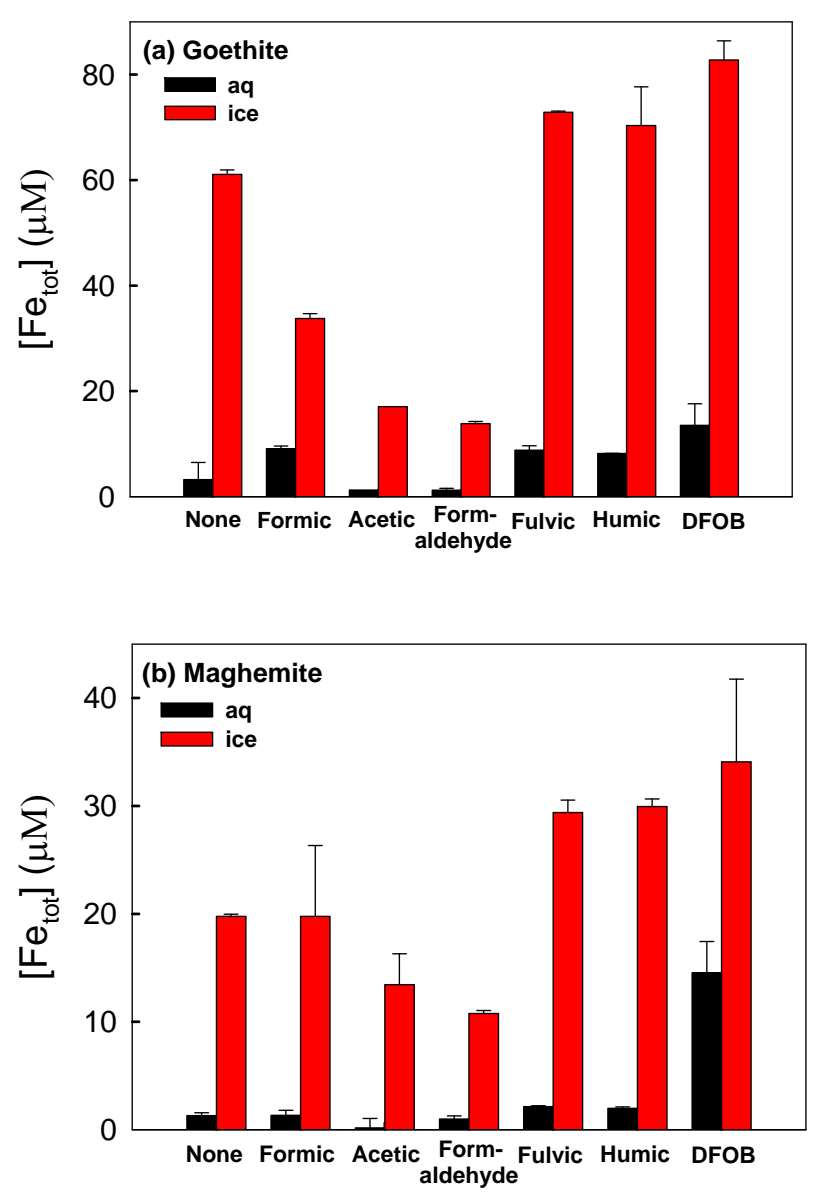

Fig. 1. Production of total dissolved iron from (a) goethite $(\alpha$ $\mathrm{FeOOH})$ and (b) maghemite $\left(\gamma-\mathrm{Fe}_{2} \mathrm{O}_{3}\right)$ under dark condition in the presence of various organic complexing ligands in water $\left(25^{\circ} \mathrm{C}\right)$ and ice $\left(-20^{\circ} \mathrm{C}\right)$ after $72 \mathrm{~h}$. Experimental conditions: $[\alpha-\mathrm{FeOOH}$ or $\left.\gamma-\mathrm{Fe}_{2} \mathrm{O}_{3}\right]_{i}=0.2 \mathrm{~g} \mathrm{~L}^{-1}$, [organic ligand] $=6 \mathrm{mM}$, [fulvic or humic acid $]=1 \mathrm{ppm},[\mathrm{DFOB}]=50 \mu \mathrm{M}$, and $\mathrm{pH}_{i}=3.00 \pm 0.05$.

1,10-phenanthroline and $1.5 \mathrm{~mL}$ of ammonium acetate buffer to the vial containing $1.5 \mathrm{~mL}$ of the filtered sample. The vial was then vigorously mixed and kept for $1 \mathrm{~h}$ in the dark before analysis. The total dissolved iron $\left(\mathrm{Fe}^{2+}+\mathrm{Fe}^{3+}\right)$ was measured by the similar protocol but by adding $100 \mu \mathrm{L}$ of hydroxylamine hydrochloride which reduces all the ferric to ferrous ions. The absorbance was measured at $510 \mathrm{~nm}(\varepsilon=$ $\left.2.5 \times 10^{4} \mathrm{~L} \mathrm{~mol}^{-1} \mathrm{~cm}^{-1}\right)$ using a UV/Visible spectrophotometer (Libra S22, Biochrom). To check out the possibility that some dissolved iron may re-precipitate before the analysis, the samples were also kept in dark for $24 \mathrm{~h}$ before measurement. The analysis result was not different from that obtained right after thawing. To assure the results of the colorimetric analysis, some samples were also analyzed by atomic absorption spectroscopy (AAS, SpectrAA-800) and the determined concentration of the total dissolved iron was within $5 \%$ difference from that obtained by the above colorimetric analysis. The iron oxide samples with DFOB was analyzed only by AAS because of the strong affinity between ferric and DFOB. Deionized water used was ultrapure $(18 \mathrm{M} \Omega \mathrm{cm})$ and prepared by a Barnstead purification system.

\section{Results and discussion}

\subsection{Enhanced production of iron from iron oxides in ice}

Series of heterogeneous dissolution experiments were conducted with various commercial iron oxides (nanosized particles) in the presence of selected organic complexing ligands. Among several iron oxides, goethite and maghemite were mainly investigated because of the abundance in the environment and the facility in performing the experiments (e.g. good suspension and high surface area). All the iron oxide dissolution experiments were conducted in both aqueous and ice phase under dark. Figure 1 shows that the production of total dissolved iron $\left(\mathrm{Fe}^{2+}+\mathrm{Fe}^{3+}\right)$ from both goethite (Fig. 1a) and maghemite (Fig. 1b) was markedly enhanced in ice phase compared to the aqueous samples regardless of the presence of organic complexing ligands. At similar conditions (i.e. type and concentration of iron oxide and organic acid, $\mathrm{pH}$, and reaction time), the iron dissolution rates in ice were much slower than the previously reported rate of photoreductive dissolution in ice (by 7-8 times) but the trend remained the same (Kim et al., 2010). Most of the iron oxide samples in aqueous solution that were kept at ambient temperature for $72 \mathrm{~h}$ produced insignificant amount of dissolved iron compared to the ice counterparts. However, the aqueous samples with DFOB produced around $15 \mu \mathrm{M}$ (about $6 \%$ of the initial iron oxide) of total dissolved iron from both goethite and maghemite, which reflects the strong iron binding character of DFOB in the aqueous phase (Borer et al., 2009). It should be noted that the iron dissolution in ice was clearly observed even in the absence of organic complexing ligands and the addition of organic acids like formic and acetic acid little changed or even reduced the dissolution rate. This indicates that the observed dissolution of iron oxide is not a reductive process unlike the case of photoreductive dissolution that essentially requires the presence of organic ligands (Kim et al., 2010). The rate of iron dissolution in ice was particularly fast in the presence of fulvic, humic acid, and DFOB, all of which may form a strong complexation with dissolved irons. This implies that the enhancement with these organics is mainly driven by the ligand-enhanced dissolution.

Figure 2 compared the iron dissolution from commercial samples of maghemite, goethite, magnetite, hematite, and lepidocrocite after $72 \mathrm{~h}$ reaction in the dark. The dissolution rate of iron oxides was higher with the samples with higher surface area. Goethite which had the highest surface area $\left(178 \mathrm{~m}^{2} \mathrm{~g}^{-1}\right)$ showed the highest concentration of dissolved iron $(61 \pm 1 \mu \mathrm{M})$ after $72 \mathrm{~h}$ in the 
Table 2. Initial dissolution rates of different iron oxides in the presence and absence of various organic ligand ${ }^{\mathrm{a}}$.

\begin{tabular}{|c|c|c|c|c|c|c|c|c|c|c|}
\hline \multirow{3}{*}{$\begin{array}{l}\text { Organic } \\
\text { Ligand }\end{array}$} & \multicolumn{10}{|c|}{ Initial Rates $\left(10^{-8} \mathrm{~mol} \mathrm{~L}^{-1} \mathrm{~h}^{-1}\right)$} \\
\hline & \multicolumn{2}{|c|}{$\begin{array}{r}\gamma-\mathrm{Fe}_{2} \mathrm{O}_{3} \\
\text { (maghemite) }\end{array}$} & \multicolumn{2}{|c|}{$\begin{array}{r}\alpha-\mathrm{FeOOH} \\
\text { (goethite) }\end{array}$} & \multicolumn{2}{|c|}{$\begin{array}{r}\mathrm{Fe}_{3} \mathrm{O}_{4} \\
\text { (magnetite) }\end{array}$} & \multicolumn{2}{|c|}{$\begin{array}{r}\alpha-\mathrm{Fe}_{2} \mathrm{O}_{3} \\
\text { (hematite) }\end{array}$} & \multicolumn{2}{|c|}{$\begin{array}{r}\gamma-\mathrm{FeOOH} \\
\text { (lepidocrocite) }\end{array}$} \\
\hline & $\mathrm{aq}$ & ice & $\mathrm{aq}$ & ice & $\mathrm{aq}$ & ice & $\mathrm{aq}$ & ice & $\mathrm{aq}$ & ice \\
\hline \multirow[t]{2}{*}{ None } & 6.3 & 41.1 & 8.8 & 187.0 & 15.3 & 22.9 & 1.8 & 3.9 & 1.1 & 44.7 \\
\hline & $(0.9)^{b}$ & $(5.7)$ & $(0.2)$ & $(5.3)$ & $(1.5)$ & (2.3) & (1.1) & $(2.4)$ & $(0.1)$ & (3.0) \\
\hline Formic acid & 8.4 & 59.3 & 24.1 & 98.7 & - & - & - & - & 2.8 & 15.3 \\
\hline Acetic acid & 5.1 & 37.3 & 7.2 & 45.5 & - & - & - & - & 0.4 & 14.0 \\
\hline Formaldehyde & 6.6 & 41.5 & 5.1 & 43.6 & - & - & - & - & - & - \\
\hline Fulvic acid & 10.5 & 104.8 & 18.7 & 224.4 & 12.2 & 35.1 & 0.7 & 2.2 & - & - \\
\hline Humic acid & 7.8 & 79.3 & 20.1 & 231.4 & 14.0 & 36.3 & 2.2 & 3.1 & - & - \\
\hline DFOB & 38.6 & 96.5 & 35.8 & 162.5 & - & - & - & - & 17.4 & 43.0 \\
\hline
\end{tabular}

${ }^{\mathrm{a}}$ Experimental condition: [iron oxide $]_{i}=0.2 \mathrm{~g} \mathrm{~L}^{-1}, \mathrm{pH}_{i}=3$. [formic, acetic, or formaldehyde] $=6 \mathrm{mM},[\mathrm{FA}$ or HA$]=1 \mathrm{ppm}$,

$[\mathrm{DFOB}]=50 \mu \mathrm{M}$. The initial rate was determined after $24 \mathrm{~h}$ reaction at $20-25^{\circ} \mathrm{C}$ for aqueous samples and $-20^{\circ} \mathrm{C}$ for ice samples.

$\mathrm{b}$ Values in the parentheses are the initial dissolution rates $\left(10^{-8} \mathrm{~mol} \mathrm{~m}^{-2} \mathrm{~h}^{-1}\right)$ of iron oxides per surface area basis.

ice. Maghemite $(19 \pm 1 \mu \mathrm{M})$, magnetite $(30 \pm 1 \mu \mathrm{M})$, and lepidocrocite $(29 \pm 8 \mu \mathrm{M})$ which had similar surface areas of 36,50 , and $75 \mathrm{~m}^{2} \mathrm{~g}^{-1}$ respectively, produced similar concentration level of dissolved iron, which is lower than that of goethite. Hematite with the lowest surface area $\left(8 \mathrm{~m}^{2} \mathrm{~g}^{-1}\right)$ exhibited the lowest rate of iron dissolution. Table 2 summarizes the initial iron dissolution rates which were obtained using various iron oxides and organic complexing ligands. For the dissolution rates in the absence of organic ligands, the values normalized by the surface area are also compared (numbers in the parentheses). It is noted that the surface areanormalized dissolution rates much less vary among the different iron oxides than the apparent dissolution rates do: the apparent dissolution rate of goethite and hematite in ice is 187 vs. 3.9 while its surface area-normalized counterpart is 5.3 vs. 2.4. Therefore, the key parameter that determines the dissolution rate of iron oxides in ice should be the surface area, not the crystallinity.

The speciation of the dissolved iron $\left(\mathrm{Fe}^{2+}\right.$ vs. $\left.\mathrm{Fe}^{3+}\right)$ was also determined and the time profiles of each species are shown for both goethite (Fig. 3a) and maghemite (Fig. 3b). Regardless of the presence or kind of organic complexing ligands, most of the dissolved iron was in the ferric form $\left(\mathrm{Fe}^{3+}=\mathrm{Fe}_{\text {tot }}-\mathrm{Fe}^{2+}\right)$ and the production of $\mathrm{Fe}^{2+}$ was negligible, which confirms that the dissolution is not a reductive process. On the contrary, in the presence of light and organic ligands (e.g. DFOB), the majority of the species dissolved from iron (hydr)oxides was reported to be in the ferrous form generated through the photoreductive process (Borer et al., 2009; Pehkonen et al., 1993; Siefert et al., 1994). For both goethite (Fig. 3a) and maghemite (Fig. 3b), fulvic acid enhanced the dissolution rate whereas acetic acid retarded it, compared to the case without organic ligands. This indicates that the complexing ability of ligands critically affects the iron dissolution process. To investigate this effect further, two organic ligands, DFOB (as a strong multiden-

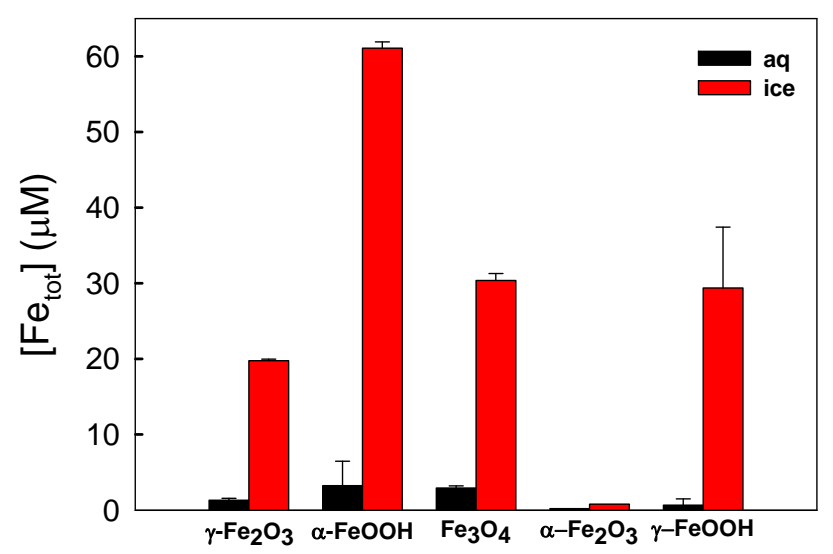

Fig. 2. Dissolved iron formation from various iron oxides in the absence of organic complexing ligand under dark condition. Aqueous samples (black) were maintained at room temperature and ice samples (red) at $-20^{\circ} \mathrm{C}$ for $72 \mathrm{~h}$. Experimental conditions: [iron oxide $]=0.2 \mathrm{~g} \mathrm{~L}^{-1}$ and $\mathrm{pH}_{i}=3.00 \pm 0.05$.

tate ligand) and acetic acid (as a weak monodentate ligand), were compared for the dissolution of goethite with varying their concentrations. Figure $4 \mathrm{a}$ shows that the presence of acetic acid has a negative effect on the iron dissolution process in the concentration range of $0-60 \mathrm{mM}$. This indicates that the adsorption of acetate on iron oxide surface hinders the dissolution process. The adsorption sites of iron oxides seemed to be saturated at $6 \mathrm{mM}$ of acetic acid since increasing the concentraion up to $60 \mathrm{mM}$ showed no further change. On the contrary, the concentration dependence of the DFOBinduced dissolution is different (Fig. 4b) and the release of iron from goethite was optimized at $[\mathrm{DFOB}]=50 \mu \mathrm{M}$.

In the previous studies, it was estimated that protons are locally concentrated in the ice grain boundary regions by $2-$ 3 orders of magnitude compared to the bulk aqueous phase 

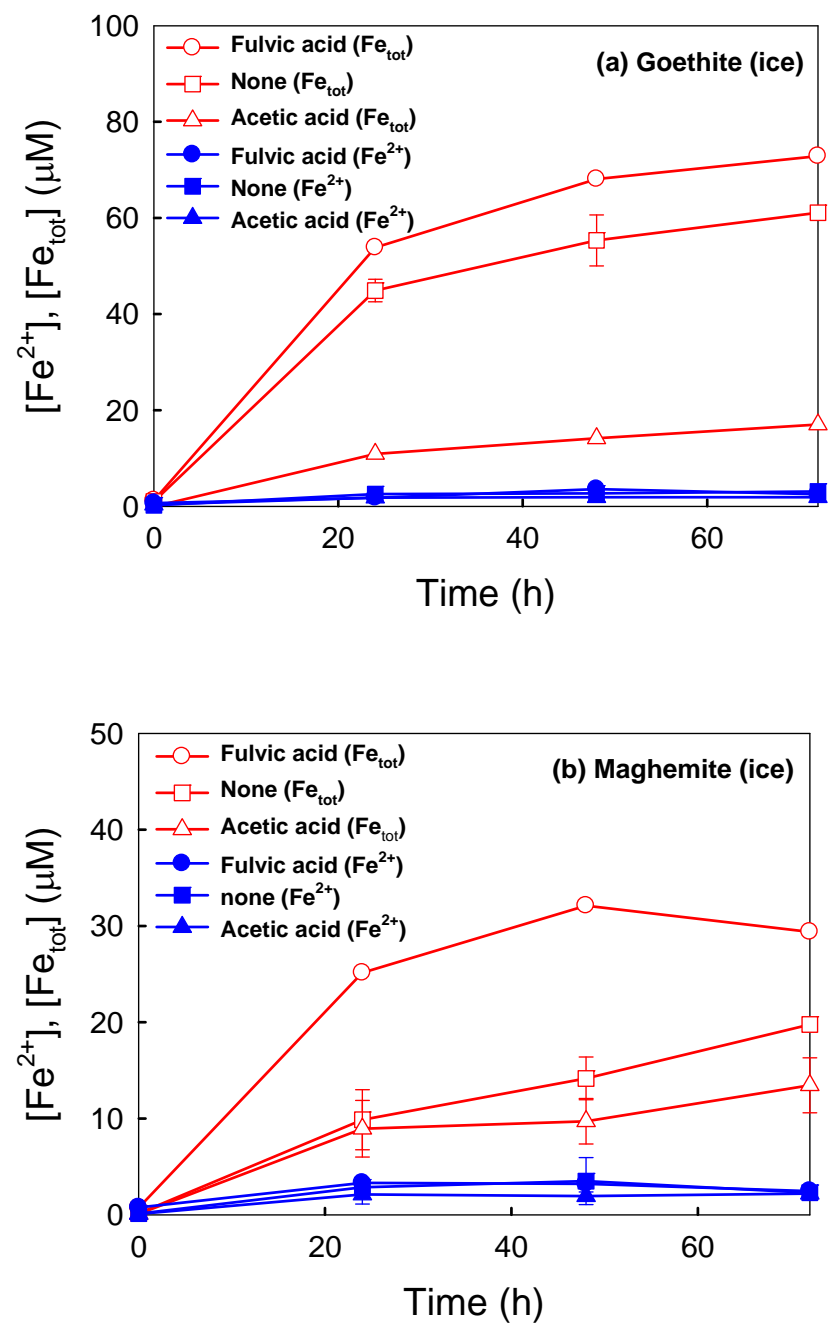

Fig. 3. The time profiles of dissolved iron $\left(\mathrm{Fe}^{2+}\right.$ and $\left.\mathrm{Fe}_{\text {tot }}\right)$ generation from iron oxides in ice: (a) goethite and (b) maghemite. Experimental conditions: $\left[\alpha-\mathrm{FeOOH} \text { or } \gamma-\mathrm{Fe}_{2} \mathrm{O}_{3}\right]_{i}=0.2 \mathrm{~g} \mathrm{~L}^{-1}$, [fulvic acid $]=1 \mathrm{ppm}$, [acetic acid] $=6 \mathrm{mM}$, and $\mathrm{pH}_{i}=3.00 \pm 0.05$.

(Heger et al., 2006; Grannas et al., 2007; Robinson et al., 2006). Since $\mathrm{pH}$ has a significant influence on the dissolution of iron oxides (Cornell, 1996), the initial iron dissolution rates were determined at various $\mathrm{pH}$ (Table 3). Total iron dissolution rates, estimated from the dissolution after $24 \mathrm{~h}$, rapidly decreased with increasing $\mathrm{pH}$. Both maghemite and goethite showed a significantly enhanced dissolution rate in ice when the initial $\mathrm{pH}$ was lower than 4 . Although goethite in ice showed somewhat higher release of dissolved iron at $\mathrm{pH} 4$ than the aqueous counterpart, it was not a significant amount compared to $\mathrm{pH} 3$ and $\mathrm{pH} 2$. All the aqueous samples showed negligible amount of total iron dissolved from iron oxide at $\mathrm{pH}>2$. The literature data of iron oxide dissolution in an aqueous solution of $\mathrm{pH} 0.3$ (Sidhu et al., 1981) (shown in Table 3) is in the comparable range with the ice
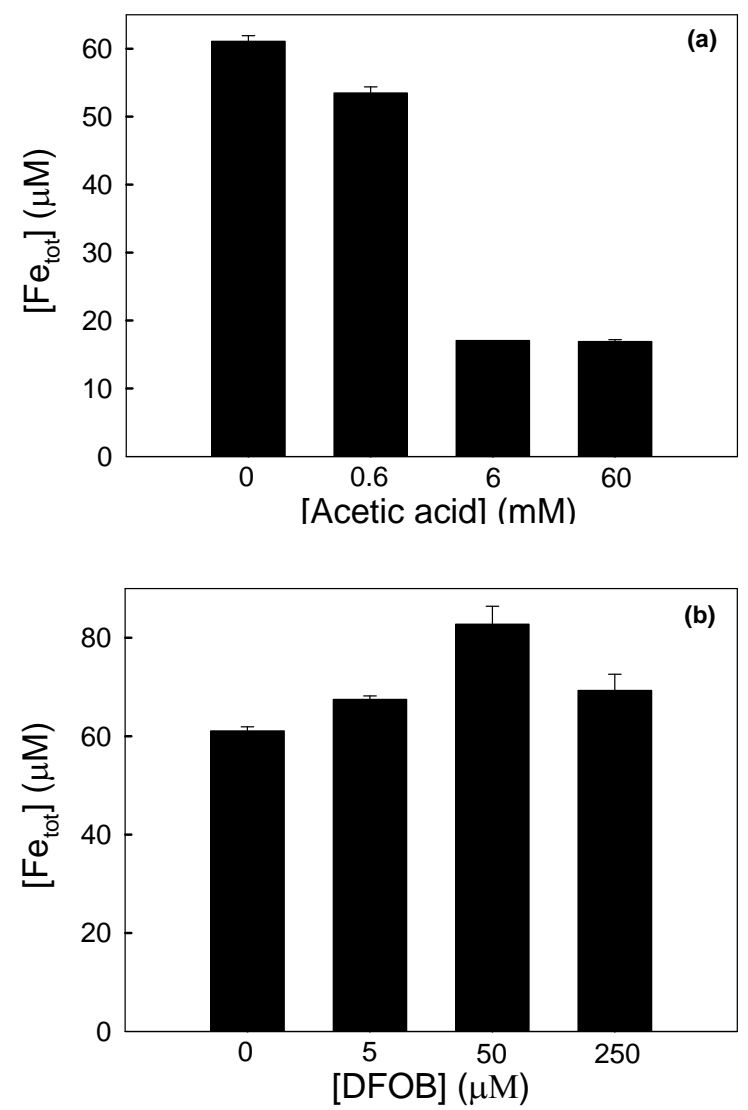

Fig. 4. Total dissolved iron generation from goethite in the presence of various concentrations of (a) acetic acid and (b) DFOB. Experimental conditions: $[\alpha-\mathrm{FeOOH}]_{i}=0.2 \mathrm{~g} \mathrm{~L}^{-1}$, and $\mathrm{pH}_{i}=3.00 \pm 0.05$.

dissolution data at $\mathrm{pH} 2-3$. This implies that the ice grain boundary region has a highly acidic environment.

The formation of the micro-sized liquid-like grain boundary regions in bulk ice greatly depends upon the freezing temperature. It has been reported that the thickness of the liquid-like layer in the ice decreases with decreasing the freezing temperature (Takenaka et al., 2006). Figure 5 shows the dissolution of maghemite investigated at various temperatures in the dark condition at $\mathrm{pH} 3$. All the samples were frozen by putting the sample tubes in the pre-set low temperatures $\left(-10,-20,-30,-70\right.$, and $\left.-196^{\circ} \mathrm{C}\right)$. In all frozen samples, the dissolution of total iron from maghemite was higher than the aqueous counterpart and lowering the freezing temperature gradually reduced the amount of the total dissolved iron. The liquid content in the grain boundary layer should decrease with decreasing the freezing temperature and be negligible below the eutectic point on which the system becomes completely solid (Takenaka and Bandow, 2007). However, reactions might occur to a weak extent even below the eutectic point (Kiovsky and Pincock, 1966; Horne, 1963). The freezing rate should depend on the temperature 
Table 3. Initial dissolution rates of different iron oxides at various $\mathrm{pH}$ in the absence of organic ligand ${ }^{\mathrm{a}}$.

\begin{tabular}{lllll}
\hline & \multicolumn{4}{c}{ Initial Rates $\left(10^{-8} \mathrm{~mol} \mathrm{~L}^{-1} \mathrm{~h}^{-1}\right)$} \\
\cline { 2 - 5 } $\mathrm{pH}_{i}$ & $\gamma-\mathrm{Fe}_{2} \mathrm{O}_{3}$ & \multicolumn{3}{c}{$\alpha$-FeOOH } \\
& $\mathrm{aq}$ & ice & $\mathrm{aq}$ & ice \\
\hline$(0.3)^{\mathrm{b}}$ & $(177)^{\mathrm{b}}$ & & $(9.5)^{\mathrm{b}}$ \\
2 & $40.7 \pm 4.1$ & $359.9 \pm 1.2$ & $243.5 \pm 3.4$ & $1159.2 \pm 19.6$ \\
& $(5.7 \pm 0.6)^{\mathrm{c}}$ & $(50.0 \pm 0.2)^{\mathrm{c}}$ & $(6.8 \pm 0.1)^{\mathrm{c}}$ & $(32.6 \pm 0.6)^{\mathrm{c}}$ \\
3 & $6.3 \pm 4.0$ & $41.1 \pm 13.0$ & $8.8 \pm 5.3$ & $187.0 \pm 9.8$ \\
& $(0.9 \pm 0.6)^{\mathrm{c}}$ & $(5.7 \pm 1.8)^{\mathrm{c}}$ & $(0.2 \pm 0.2)^{\mathrm{c}}$ & $(5.3 \pm 0.3)^{\mathrm{c}}$ \\
4 & $1.1 \pm 0.5$ & $0.7 \pm 0.9$ & $2.4 \pm 1.1$ & $24.0 \pm 1.2$ \\
5 & $2.9 \pm 0.5$ & $2.3 \pm 0.3$ & $2.1 \pm 0.3$ & $1.3 \pm 1.0$ \\
8 & $1.1 \pm 1.6$ & $0.6 \pm 0.9$ & $2.8 \pm 0.7$ & $2.7 \pm 0.9$ \\
\hline
\end{tabular}

a Experimental condition: $\left[\gamma-\mathrm{Fe}_{2} \mathrm{O}_{3} \text { or } \alpha-\mathrm{FeOOH}\right]_{i}=0.2 \mathrm{~g} \mathrm{~L}^{-1}$, reaction time $24 \mathrm{~h}$ at $25^{\circ} \mathrm{C}$ for aqueous samples and $-20^{\circ} \mathrm{C}$ for ice.

${ }^{\mathrm{b}}$ Literature data taken from the study of Sidhu et al. (1981) in the unit of $\left(10^{-8}\right.$ $\mathrm{mol} \mathrm{m}^{-2} \mathrm{~h}^{-1}$ ).

${ }^{c}$ Values in the parentheses are the initial dissolution rates $\left(10^{-8} \mathrm{~mol} \mathrm{~m}^{-2} \mathrm{~h}^{-1}\right)$ of iron oxides per surface area basis.

as well. Although the freezing rate could not be controlled in this work, it should be faster at lower temperatures. At fast freezing conditions $\left(-70\right.$ and $\left.-196^{\circ} \mathrm{C}\right)$, the solutes might have little time to migrate and concentrate in the grain boundary regions (Heger et al., 2005). On the other hand, when the freezing process is slow enough at higher temperature $\left(>-30^{\circ} \mathrm{C}\right)$, the iron oxide particles and other solutes may have sufficient time to be gradually concentrated at the grain boundaries. Overall, lowering freezing temperature influences the dissolution of iron oxides in ice in a complex way. It may enhance the freeze concentration effect by reducing the liquid content in the grain boundaries whereas it may cause an opposite effect by retarding the migration of the solutes during the freezing process. Judging from the result of Fig. 5, the latter effect seems to prevail. The temperaturedependent results imply that the existence of liquid-like grain boundaries plays an important role in the ice-induced dissolution of iron oxides.

\subsection{Dissolution mechanisms}

When ice crystals begin to form, iron oxides, organic substances, and protons are concentrated in the ice grain boundary region according to "freeze concentration effect". The ice-enhanced production of $\mathrm{Fe}^{3+}$ from iron oxide under dark condition is possibly ascribed to the proton concentration in the ice grain boundary region ( $\mathrm{pH}$ effect) where the iron oxide particles are agglomerated (Kim et al., 2010). Adsorption of protons to surface hydroxyl groups on iron oxide may promote the dissolution of ferric ions (Schwertmann, 1991). The dissolved ferric ions can be hydrolyzed or chelated by organic ligands. Under irradiation, the ferric complexes can be reduced to ferrous ions that are more bioavailable. The dissolution of iron oxides is generally promoted by proton-

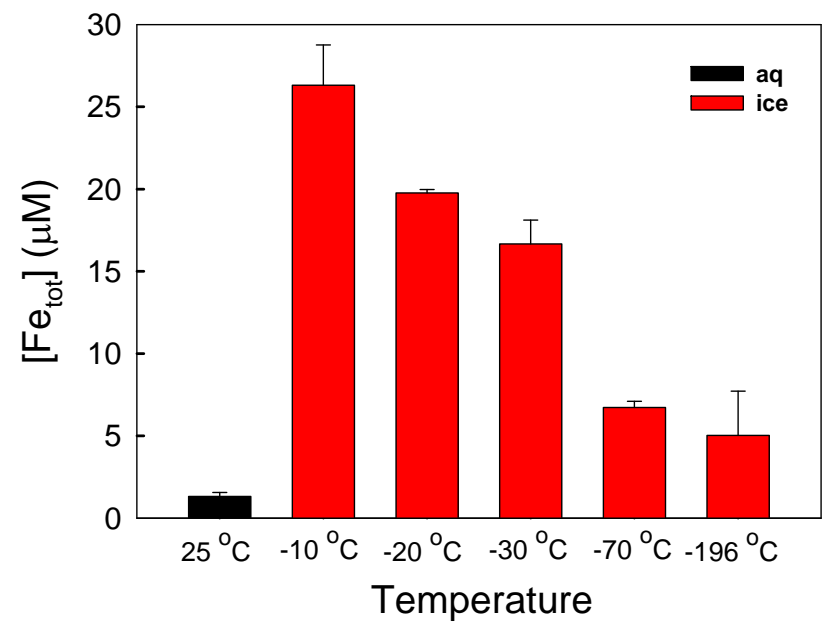

Fig. 5. Temperature dependence of iron dissolution from maghemite in the absence of organic complexing ligand. Aqueous samples (black) were maintained at room temperature and ice samples (red) at $-10,-20,-30,-70$, and $-196^{\circ} \mathrm{C}$. Experimental conditions: $\left[\gamma-\mathrm{Fe}_{2} \mathrm{O}_{3}\right]_{i}=0.2 \mathrm{~g} \mathrm{~L}^{-1}$ and $\mathrm{pH}_{i}=3.00 \pm 0.05$.

assisted (Eq. 1) and ligand-assisted (Eq. 4) process (Furrer and Stumm, 1986):

$$
\begin{aligned}
& \equiv \mathrm{Fe}^{\mathrm{III}} \mathrm{OOH}_{(\mathrm{s})}+n \mathrm{H}^{+} \rightarrow\left[\mathrm{Fe}^{\mathrm{III}}(\mathrm{OH})_{(3-n)}\right]_{(\mathrm{aq})}^{n+} \\
& +(n-1) \mathrm{H}_{2} \mathrm{O} \\
& \equiv \mathrm{Fe}^{\mathrm{III}} \mathrm{OOH}_{(\mathrm{s})}+\mathrm{H}^{+} \rightarrow \equiv \mathrm{Fe}^{\mathrm{III}}(\mathrm{OH})_{2(\mathrm{~s})}^{+} \\
& \equiv \mathrm{Fe}^{\mathrm{III}}(\mathrm{OH})_{2(\mathrm{~s})}^{+}+2 \mathrm{H}^{+} \rightarrow \mathrm{Fe}^{3+}{ }_{(\mathrm{aq})}+2 \mathrm{H}_{2} \mathrm{O} \\
& \equiv \mathrm{Fe}^{\mathrm{III}}-\mathrm{OH}+\mathrm{L}^{-}+\mathrm{H}^{+} \rightarrow \equiv \mathrm{Fe}^{\mathrm{III}} \mathrm{L}+\mathrm{H}_{2} \mathrm{O} \\
& \rightarrow\left[\mathrm{Fe}^{\mathrm{III}} \mathrm{L}\right]_{(\mathrm{aq})}+\mathrm{H}_{2} \mathrm{O}
\end{aligned}
$$

The proton-assisted dissolution (Eq. 1) can be described by two consecutive steps. First, a proton is adsorbed on the surface $\mathrm{O}$ atom to generate surface hydroxyl group (Eq. 2). Next, two more protons are adsorbed weakening the Fe-O bond by polarizing it and eventually $\mathrm{Fe}^{3+}$ ion is released into the solution (Eq. 3). In the ice grain boundary regions, the concentrated protons would readily protonate the iron oxide surface and thus release more $\mathrm{Fe}^{3+}$ ions into the ice grain boundaries.

Another mechanism is the ligand-promoted dissolution. Enhanced dissolution of iron oxides in the presence of multidentate ligands has long been studied in the aqueous phase (Kraemer, 2004; Rose and Waite, 2003). Strong iron-binding multidentate ligands efficiently enhance the dissolution of 
iron oxides by forming surface chelation replacing the surface hydroxyl groups (Eq. 4). Upon freezing, the concentrated organic ligands (fulvic acid, humic acid, and DFOB) in the ice grain boundaries should serve as efficient iron chelating agents to further enhance the release of dissolved iron as shown in Figs. 1 and 4. However, monodentate organic ligands (acetic acid, formic acid, and formaldehyde) did not enhance the iron dissolution in ice compared with that in the absence of organic ligand (Figs. 1 and 4). Monodentate ligands, unlike multidentate ligands, are known to form much weaker surface complexes with irons and may not enhance the dissolution rate (Furrer and Stumm, 1986). These weak monodentate ligands can inhibit iron dissolution by blocking the active sites for chelating ligands (Furrer and Stumm, 1986) or protons (Schwertmann, 1991). In the ice grain boundaries, the concentrated monodentate ligands may block the iron oxide active sites from protonation and thus hinder the dissolution of iron as shown in Figs. 1 and 4.

\section{Summary and outlook}

This work investigated the iron oxide dissolution reactions in the aqueous and ice phase under dark condition. The dissolution of iron oxides greatly increased when they were trapped in ice and the ice-enhanced effect depended on the kind of organic ligand, $\mathrm{pH}$, and the type and surface area of iron oxides. Since all the experiments were conducted in the absence of light, the present finding generalizes the special case of photoreductive dissolution in ice which we recently reported (Kim et al., 2010). The results impose important implications on the redox cycling of iron in icy environments such as polar region, upper atmosphere, and frozen soils. Especially, in upper atmosphere or mid-winter polar regions, iron containing dust particles can be trapped in ice and subsequently provide labile ferric ions upon thawing to their receiving environment. The transport of aeolian dust particles and their subsequent deposition is thought to be the major source of bioavailable iron in the open ocean. These dust particles contain iron (typically a few percent) (Warneck, 1988) and serve as ice nuclei in the upper troposphere (Pruppacher and Klett, 1997). The typical cloud $\mathrm{pH}$ is 3.5 and marine aerosol solution can be as low as pH 1.0 (Zhuang et al., 1992). Since the $\mathrm{pH}$ in the ice grain boundary can be much lower, iron oxides in the frozen dust particles will undergo enhanced dissolution and eventually provide more bioavailable iron upon deposition. These labilized ferric ions can form complexes with ligands or $\mathrm{OH}$ groups and subsequently undergo photochemical or biological reduction in reducing environments. In general, the proposed phenomenon can be limited to environments with acidic ice such as the upper atmosphere. However, careful demonstration should be taken in order to extrapolate any laboratory results to natural environment. Various factors including dissolved substrates (organic and inorganic), ionic strength, microorganisms, and crystallinity, surface de- fects, and size of iron-containing minerals can contribute to the reactions taking place in the ice grain boundary regions. The dissolution process may be initiated inhomogeneously at the surface defect sites, which should be characterized at the molecular level. Careful control studies are required to understand the effect of each factor involved in the dissolution process and to verify the laboratory results for their implications in natural environmental conditions.

Acknowledgements. This work was supported by the KOSEF NRL program (no. R0A-2008-000-20068-0), the KOSEF EPB Center (grant no. R11-2008-052-02002), and Korea Polar Research Institute (PP12020), and the "Polar Academic Program (PAP)" of the Korea Polar Research Institute (KOPRI).

Edited by: M. Ammann

\section{References}

Alexova, R., Fujii, M., Birch, D., Cheng, J., Waite, T. D., Ferrari, B. C., and Neilan, B. A.: Iron uptake and toxin synthesis in the bloom-forming Microcystis aeruginosa under iron limitation, Environ. Microbiol., 13, 1064-1077, 2011.

Bligh, M. W. and Waite, T. D.: Formation, aggregation and reactivity of amorphous ferric oxyhydroxides on dissociation of Fe(III)organic complexes in dilute aqueous suspensions, Geochim. Cosmochim. Ac., 74, 5746-5762, 2010.

Borer, P., Sulzberger, B., Hug, S. J., Kraemer, S. M., and Kretzschmar, R.: Photoreductive dissolution of iron(III) (hydr)oxides in the absence and presence of organic ligands: experimental studies and kinetic modeling, Environ. Sci. Technol., 43, 18641870, doi:10.1021/Es801352k, 2009.

Boxe, C. S. and Saiz-Lopez, A.: Multiphase modeling of nitrate photochemistry in the quasiliquid layer (QLL): implications for $\mathrm{NO}_{\mathrm{x}}$ release from the Arctic and coastal Antarctic snowpack, Atmos. Chem. Phys., 8, 4855-4864, doi:10.5194/acp-8-4855-2008, 2008.

Cheng, J., Soetjipto, C., Hoffmann, M. R., and Colussi, A. J.: Confocal fluorescence microscopy of the morphology and composition of interstitial fluids in freezing electrolyte solutions, J. Phys. Chem. Lett., 1, 374-378, doi:10.1021/Jz9000888, 2010.

Cornell, R. M. and Schwertmann, U.: The Iron Oxides: Structure, Properties, Reactions, Occurrence and Uses, Wiley-VCH, New York, 268-272, 1996.

Falkowski, P. G., Barber, R. T., and Smetacek, V.: Biogeochemical controls and feedbacks on ocean primary production, Science, 281, 200-206, doi:10.1126/science.281.5374.200, 1998.

Fan, S. M., Moxim, W. J., and Levy, H.: Aeolian input of bioavailable iron to the ocean, Geophys. Res. Lett., 33, L07602, doi:10.1029/2005g1024852, 2006.

Faust, B. C. and Hoffmann, M. R.: Photoinduced reductive dissolution of $\alpha-\mathrm{Fe}_{2} \mathrm{O}_{3}$ by bisulfite, Environ. Sci. Technol., 20, 943948, 1986.

Furrer, G. and Stumm, W.: The coordination chemistry of weathering: I. Dissolution kinetics of $\delta-\mathrm{Al}_{2} \mathrm{O}_{3}$ and $\mathrm{BeO}$, Geochim. Cosmochim. Ac., 50, 1847-1860, 1986. 
Grannas, A. M., Jones, A. E., Dibb, J., Ammann, M., Anastasio, C., Beine, H. J., Bergin, M., Bottenheim, J., Boxe, C. S., Carver, G., Chen, G., Crawford, J. H., Dominé, F., Frey, M. M., Guzmán, M. I., Heard, D. E., Helmig, D., Hoffmann, M. R., Honrath, R. E., Huey, L. G., Hutterli, M., Jacobi, H. W., Klán, P., Lefer, B., McConnell, J., Plane, J., Sander, R., Savarino, J., Shepson, P. B., Simpson, W. R., Sodeau, J. R., von Glasow, R., Weller, R., Wolff, E. W., and Zhu, T.: An overview of snow photochemistry: evidence, mechanisms and impacts, Atmos. Chem. Phys., 7, 43294373, doi:10.5194/acp-7-4329-2007, 2007.

Guzman, M. I., Hildebrandt, L., Colussi, A. J., and Hoffmann, M. R.: Cooperative hydration of pyruvic acid in ice, J. Am. Chem. Soc., 128, 10621-10624, doi:10.1021/Ja062039v, 2006.

Guzman, M. I., Hoffmann, M. R., and Colussi, A. J.: Photolysis of pyruvic acid in ice: Possible relevance to $\mathrm{CO}$ and $\mathrm{CO}_{2}$ ice core record anomalies, J. Geophys. Res.-Atmos., 112, D10123, doi:10.1029/2006jd007886, 2007.

Heger, D., Jirkovsky, J., and Klan, P.: Aggregation of methylene blue in frozen aqueous solutions studied by absorption spectroscopy, J. Phys. Chem. A, 109, 6702-6709, doi:10.1021/Jp050439j, 2005.

Heger, D., Klánová, J., and Klán, P.: Enhanced protonation of cresol red in acidic aqueous solutions caused by freezing, J. Phys. Chem. B, 110, 1277-1287, doi:10.1021/jp0553683, 2006.

Horne, R. A.: Kinetics of the iron(II)-iron(III) electron exchange reaction in ice media, J. Inorg. Nucl. Chem., 25, 1139-1146, 1963.

Jickells, T. D., An, Z. S., Andersen, K. K., Baker, A. R., Bergametti, C., Brooks, N., Cao, J. J., Boyd, P. W., Duce, R. A., Hunter, K. A., Kawahata, H., Kubilay, N., LaRoche, J., Liss, P. S., Mahowald, N., Prospero, J. M., Ridgwell, A. J., Tegen, I., and Torres, R.: Global iron connections between desert dust, ocean biogeochemistry, and climate, Science, 308, 67-71, doi:10.1126/science.1105959, 2005.

Journet, E., Desboeufs, K. V., Caquineau, S., and Colin, J. L.: Mineralogy as a critical factor of dust iron solubility, Geophys. Res. Lett., 35, L07805, doi:10.1029/2007gl031589, 2008.

Kim, K. and Choi, W.: Enhanced redox conversion of chromate and arsenite in ice, Environ. Sci. Technol., 45, 2202-2208, doi:10.1021/es103513u, 2011.

Kim, K., Choi, W., Hoffmann, M. R., Yoon, H. I., and Park, B. K.: Photoreductive dissolution of iron oxides trapped in ice and its environmental implications, Environ. Sci. Technol., 44, 41424148, doi:10.1021/Es9037808, 2010.

Kiovsky, T. E. and Pincock, R. E.: Demonstration of a reaction in frozen aqueous solutions, J. Chem. Educ., 43, 361-362, 1966.

Kraemer, S. M.: Iron oxide dissolution and solubility in the presence of siderophores, Aquat. Sci., 66, 3-18, doi:10.1007/s00027-0030690-5, 2004.

Kuo, M. H., Moussa, S. G., and McNeill, V. F.: Modeling interfacial liquid layers on environmental ices, Atmos. Chem. Phys., 11, 9971-9982, doi:10.5194/acp-11-9971-2011, 2011.

Mahowald, N. M., Baker, A. R., Bergametti, G., Brooks, N., Duce, R. A., Jickells, T. D., Kubilay, N., Prospero, J. M., and Tegen, I.: Atmospheric global dust cycle and iron inputs to the ocean, Global Biogeochem. Cy., 19, GB4025, doi:10.1029/2004GB002402, 2005.

McNeill, V. F., Grannas, A. M., Abbatt, J. P. D., Ammann, M., Ariya, P., Bartels-Rausch, T., Domine, F., Donaldson, D. J., Guzman, M. I., Heger, D., Kahan, T. F., Klán, P., Masclin, S., Toubin,
C., and Voisin, D.: Organics in environmental ices: sources, chemistry, and impacts, Atmos. Chem. Phys. Discuss., 12, 88578920, doi:10.5194/acpd-12-8857-2012, 2012.

Morel, F. M. M. and Price, N. M.: The biogeochemical cycles of trace metals in the oceans, Science, 300, 944-947, doi:10.1126/science.1083545, 2003.

Pehkonen, S. O., Siefert, R., Erel, Y., Webb, S., and Hoffmann, M. R.: Photoreduction of iron oxyhydroxides in the presence of important atmospheric organic compounds, Environ. Sci. Technol., 27, 2056-2062, 1993.

Pruppacher, H. R. and Klett, J. D.: Microphysics of Clouds and Precipitation, Kluwer Acad., Norwell, MA, 3-4, 1997.

Robinson, C., Boxe, C. S., Guzman, M. I., Colussi, A. J., and Hoffmann, M. R.: Acidity of frozen electrolyte solutions, J. Phys. Chem. B, 110, 7613-7616, doi:10.1021/Jp061169n, 2006.

Rose, A. L. and Waite, T. D.: Kinetics of iron complexation by dissolved natural organic matter in coastal waters, Mar. Chem., 84, 85-103, 2003.

Rubasinghege, G., Lentz, R. W., Scherer, M. M., and Grassian, V. H.: Simulated atmospheric processing of iron oxyhydroxide minerals at low $\mathrm{pH}$ : roles of particle size and acid anion in iron dissolution, P. Natl. Acad. Sci. USA, 107, 6628-6633, doi:10.1073/pnas.0910809107, 2010.

Schwertmann, U.: Solubility and dissolution of iron oxides, Plant Soil, 130, 1-25, doi:10.1007/bf00011851, 1991.

Shi, Z., Bonneville, S., Krom, M. D., Carslaw, K. S., Jickells, T. D., Baker, A. R., and Benning, L. G.: Iron dissolution kinetics of mineral dust at low $\mathrm{pH}$ during simulated atmospheric processing, Atmos. Chem. Phys., 11, 995-1007, doi:10.5194/acp11-995-2011, 2011a.

Shi, Z. B., Woodhouse, M. T., Carslaw, K. S., Krom, M. D., Mann, G. W., Baker, A. R., Savov, I., Fones, G. R., Brooks, B., Drake, N., Jickells, T. D., and Benning, L. G.: Minor effect of physical size sorting on iron solubility of transported mineral dust, Atmos. Chem. Phys., 11, 8459-8469, doi:10.5194/acp-11-84592011, 2011b.

Sidhu, P. S., Gilkes, R. J., Cornell, R. M., Posner, A. M., and Quirk, J. P.: Dissolution of iron oxides and oxyhydroxides in hydrochloric and perchloric acids, Clay Clay Miner., 29, 269-276, 1981.

Siefert, R. L., Pehkonen, S. O., Erel, Y., and Hoffmann, M. R.: Iron photochemistry of aqueous suspensions of ambient aerosol with added organic acids, Geochim. Cosmochim. Ac., 58, 3271-3279, 1994.

Stucki, J. W. and Anderson, W. L.: The quantitative assay of minerals for $\mathrm{Fe}^{2+}$ and $\mathrm{Fe}^{3+}$ using 1,10-Phenanthroline 1, Sources of variability, Soil Sci. Soc. Am. J., 45, 633-637, 1981.

Takenaka, N. and Bandow, H.: Chemical kinetics of reactions in the unfrozen solution of ice, J.Phys. Chem. A, 111, 8780-8786, 2007.

Takenaka, N., Ueda, A., and Maeda, Y.: Acceleration of the rate of nitrite oxidation by freezing in aqueous solution, Nature, 358 , 736-738, 1992.

Takenaka, N., Ueda, A., Daimon, T., Bandow, H., Dohmaru, T., and Maeda, Y.: Acceleration mechanism of chemical reaction by freezing: the reaction of nitrous acid with dissolved oxygen, J. Phys. Chem., 100, 13874-13884, 1996.

Takenaka, N., Tanaka, M., Okitsu, K., and Bandow, H.: Rise in the $\mathrm{pH}$ of an unfrozen solution in ice due to the presence of $\mathrm{NaCl}$ and promotion of decomposition of gallic acids owing 
to a change in the $\mathrm{pH}$, J. Phys. Chem. A, 110, 10628-10632, doi:10.1021/jp0634095, 2006.

Tortell, P. D., Maldonado, M. T., and Price, N. M.: The role of heterotrophic bacteria in iron limited ocean ecosystems, Nature, 383, 330-332, doi:10.1038/383330a0, 1996.

Waite, T. D. and Morel, F. M. M.: Photoreductive dissolution of colloidal iron oxides in natural waters, Environ. Sci. Technol., 18, 860-868, 1984.
Warneck, P.: Chemistry of the Natural Atmosphere, Academic Press, San Diego, CA, 421-450, 2000.

Zhuang, G., Yi, Z., Duce, R. A., and Brown, P. R.: Link between iron and sulphur cycles suggested by detection of $\mathrm{Fe}(\mathrm{II})$ in remote marine aerosols, Nature, 355, 537-539, 1992. 